\title{
Interactive Patterns and Teacher Talk Features in an EFL Reading Class in a Chinese University- A Case Study with Communicative Teaching Method
}

\author{
Ping Zhang \\ School of Foreign Language Studies, Nanjing University of Aeronautics and Astronautics, China \\ Email: zhangp@nuaa.edu.cn
}

\begin{abstract}
The purpose of this case study is to explore the patterns of teacher-student interaction and the strategies that the teacher adopts to facilitate student learning and promote comprehension in a reading class in a Chinese university. The researcher made an audio-recording of one session of the reading class she taught, transcribed the recording and analyzed the teacher-student interaction, looked into teacher talk and student talk. The emphasis was on teacher-talk. The study finds that the interaction pattern in this reading class follows the IRF (Initiation-Response-Feedback) or IRE (Initiation-Response-Evaluation) pattern recognized by many researchers. In order to promote understanding and elicit student responses, the teacher consciously repeats her questions and chooses alternative and tag questions. The teacher's feedback toward students' responses in class is to encourage and guide the students' inductive or deductive thinking. The research helps the teacher to find strengths and weaknesses in her way of organizing class activities and some language issues which she had not previously realized. The findings of the research may shed some light on the problems that non-native English teachers face and help them to consciously improve their instructional language as well as teaching strategies on their way of professional development.
\end{abstract}

Index Terms - teacher talk, IRF or IRE patterns, repetition, self-correction, feedback

\section{INTRODUCTION}

Communicative Approach has been adopted by many language teachers since it was introduced in China in the early 1990s. According to this approach, the teacher's role is primarily to facilitate communication. Teachers are supposed to elicit more student talk in a class conducted in such a manner. Some people even advocate that in the course of classroom teaching, teacher talk should occupy as less time as possible, leaving students more opportunities to apply what they have learnt to practical communication. Too much occupation of the time by teacher's talk would only frustrate students' initiative and restrain the development of students' language potential and creativity. (Meng \& Wang, 2011)

Then what happens in the EFL reading classroom conducted in the communicative approach in Chinese university? I adopted a communicative method in teaching reading to 26 sophomore English majors one semester. I do this case study to look into what really happens in my class: what is the teacher-student interaction pattern and how my teacher talk helps to facilitate student learning.

Teacher-student interaction and teacher talk

Classroom lessons are socially constructed events in which interaction is managed by the teacher and the learners together. Therefore, both the teacher and the learners play a crucial role. Whatever purpose they bring into the classroom, the outcome is a "co-production" by both the teacher and the learners who jointly manage interaction as well as learning (Allwright, 1984). Interaction and interactive language constitutes a major role in EFL teaching, for a teachers' interactive language can keep an interaction going on smoothly in EFL classroom. (Rod Ellis \& Gary Barkhuizen, 2005)

Many studies of classroom discourses have identified the three-part exchange structure which is known as the IRF or IRE pattern (Sinclair \& Brazil, 1982; Edwards \& Mercer, 1987; Cazden \& Beck, 2003). "I" refers to the initiation of the dialogue by the teacher with a question and "R" corresponds to the student's response; "F" is for the feedback from the teacher or "E" for teacher evaluation. Studies have shown that more than 50\% of exchanges between teacher and students are of the IRF pattern (Cazden, 1986; Edwards \& Mercer, 1987; Wells, 1999).

Mortimer and Machado (2000) developed a two-subcategory classification: dialogic and authoritative. According to their categorization, the IRF pattern can be considered authoritative as long as the feedback from the teacher is evaluation. If, on the other hand, the feedback supplies elements to extend the student's response or to elicit new ideas and contributions from them, the IRF pattern corresponds to a dialogic function. By identifying the nature of the feedback from the teacher, whether evaluative or elaborative, we can decide on the predominant nature of the discourse, 
whether dialogic or authoritative, when these IRF patterns are used.

Researchers do not agree on the appropriateness of the IRF structure. Mercer (1995) argued that triadic dialogue is an effective means of monitoring student's understanding, in guiding student's learning and marking knowledge. In contrast, Lemke (1990) noted that IRF structure is overused in most classrooms because of a mistaken belief that it encourages students' maximum participation.

Based on episodes of teacher and whole-class interaction, Nassaji and Wells (2000) suggested that the same basic IRF structure can take a variety of forms and be employed by teachers for a wide range of functions. It is understandable that different teachers may use the same basic discourse format in many different ways and at different levels of student participation and engagement. The pattern itself is not good or bad, but the use makes the difference. As Casa and DeFranco expressed, "Thus future research should investigate the techniques implemented by teachers who do promote understanding through dialogic discourse...... the types of follow-up moves, and ...... why they teach in that manner." (Casa \& DeFranco 2002: 13)

According to Sinclair \& Brazil, "teacher talk" is the language in the classroom employed to give directions, explain activities and check students' understanding (Sinclair \& Brazil, 1982). The language employed by teachers in language classes serves as the source of input of language knowledge, and is also used to instruct language communication and organize classroom activities. The research on teacher talk began in the 1970s, pioneered by Gaies $(1977,1979)$ and Henzle (1979), followed by Long (1981, 1983), Long \& Sato(1983), Welche \& Ready (1985), Ellis (1985) and Chaudron (1988). Early studies of teacher talk have found that teachers make certain modifications in their classroom speech, including adjustments to the rate of speech, lexicon, and syntax (Gaies, 1977; Chaudron, 1982). These adjustments are apparently made by teachers in an attempt to facilitate learners' comprehension (Chaudron, 1982). In recent years, researchers such as Lindholm-Leary (2001), Seedhouse (2004), Berlin (2005), Ellis \& Barkhuizen (2005), Wright (2005), Robinson (2006) studied classroom conversation features, talk turns between teachers and learners, and how the languages teachers modify their language to manage the class well. Chinese scholars such as Zhao \& Zhao (2007) investigated how the teachers provide feedbacks to students' language errors. Inceçay (2010) analyzed the quality of a teacher's language use in a class of 16 Turkish young learners of English as a foreign language and found that there are two categories regarding teacher talk; construction and obstruction. Therefore, teachers can improve or hinder learning process through the language they use. (Zargham Ghabanchi \& Shirin Malekzadeh, 2011) Their findings are in line with the idea that effective teachers' language contributes to effective learners' output (Sinclair \& Brazil, 1982).

Scholars have found that teachers employ a lot of interactive devices such as repetition, prompting, prodding, and expansions, which would be evoking more interactions between teachers and students(Gaies, 1977, 1979; Long,1981, 1983; Ellis, 1985; Chaudron, 1988; Meng \& Wang, 2011). Meng and Wang found that "increasing wait-time to three to five seconds can increase the amount of students' participation as well as the quality of that participation." (Meng \& Wang 2011:102) Some scholars studied the language characteristic of teacher talk. Meng and Wang(2011) pointed out that EFL teachers usually use short, simple, grammatically correct sentences and general, high frequent vocabulary. Ghabanchi \& Malekzadeh(2011) investigated the action verbs used by teachers in reading classes for different levels and found that "advanced learners are more imposed to higher-level thinking processes than less advanced learners "(Ghabanchi \& Malekzadeh, 2011:14). Millrood (2004) mentioned that it is possible to improve teacher-learner congruence through a decent verbal interaction with the learners by creating an optimal condition for a productive classroom interaction.

In spite of the aforementioned large body of the studies of Teacher Talk, investigations into teacher's self evaluation of his or her own talk are not adequate. What will the language teacher find while listening to his or her own lesson recording? How can the teacher evaluate his or her own talk and what can this self-evaluation help the teacher in his or her professional development? This is the reason why I decide to make a recording of my own teaching and evaluate my own teacher talk.

\section{ReSEARCh Questions}

This case study intends to answer the following questions:

(1). What's the proportion of teacher talk(TT) vs Student Talk in this EFL reading class?

(2). What's the general pattern of TT?

(3). What techniques are implemented by the teacher to promote understanding and facilitate language learning?

\section{ReSEARCH MethodS}

\section{A. Participants}

I am the researcher and the teacher to be studied. I choose to study myself because I am generally a reflective type of person. I believe that self-reflection can help me improve my teaching skills and provide professional development. In order to obtain natural and authentic data, I audio-recorded one period of my reading class which lasted for 40 minutes. In the evening after the recording, I listened to and transcribed the class recording and reflected on the kind of techniques I used to promote students' understanding and learning and the reasons why I adopted that technique to teach 
that particular class in that manner.

The reading class that I teach consists of 26 students, who are sophomore English majors, from 19 to 21 years old. They are at low-intermediate level in terms of reading comprehension. The teaching material used was a text entitled "On Not Answering the Telephone" from the required textbook New English Course compiled by Mei Renyi et al.

The teaching objectives of the class were three folded:

(1). Learn to understand word meaning in the context

(2). Learn To paraphrase sentences.

(3). Learn word-formation of compound adjectives.

The whole teaching procedure (the whole recording lasts for 41 mins, 22 seconds ) was made up of 3 steps.

(1). Warm-up (recorded length: 9 mins 10secs)

(2). Class discussion of word meanings and sentence paraphrase (recorded length: $25 \mathrm{mins}, 17$ secs) This part mainly consists of teacher-initiated questions and students' answers

(3). Group discussion (recorded length: $7 \mathrm{mins}$ )

\section{B. Data Collection}

The data were transcribed verbatim and in terms of teacher and student turns in the evening of the recoding. All aspects of the interaction recognizable on an audio file were included, although there are places where a number of students respond at once and no individual voice is discernible. While transcribing the recording, I reflected on my teacher talk, especially the reasons why I repeated some questions or words and why I spoke the way I did.

\section{DATAANALYSIS}

\section{A. Comparison of Teacher Talk and Student Talk Quantities}

I used "word counting" function of Microsoft word to count the word numbers of each sentence spoken by the teacher and the student and compare the length of each teacher talk and student talk. Table 1 shows the length of teacher talk and student talk in each turn of teacher-student interaction.

TABLE 1.

TT AND ST DIFFERENCES IN LENGTH

\begin{tabular}{|c|c|c|c|}
\hline T-S Interaction Turn No. & TT Length (Words) & ST Length (Words) & Difference \\
\hline 1 & 3 & 2 & 1 \\
\hline 2 & 34 & 2 & 32 \\
\hline 3 & 9 & 5 & 4 \\
\hline 4 & 20 & 1 & 19 \\
\hline 5 & 17 & 16 & 1 \\
\hline 6 & 97 & 0 & 97 \\
\hline 7 & 8 & 1 & 7 \\
\hline 8 & 7 & 15 & -8 \\
\hline 9 & 47 & 8 & 39 \\
\hline 10 & 9 & 23 & -14 \\
\hline 11 & 21 & 3 & 18 \\
\hline 12 & 6 & 1 & 5 \\
\hline 13 & 11 & 28 & -17 \\
\hline 14 & 57 & 4 & 53 \\
\hline 15 & 8 & 2 & 6 \\
\hline 16 & 4 & 2 & 2 \\
\hline 17 & 19 & 13 & 6 \\
\hline 18 & 25 & 5 & 20 \\
\hline 19 & 23 & 0 & 23 \\
\hline 20 & 7 & 2 & 5 \\
\hline 21 & 5 & 4 & 1 \\
\hline 22 & 21 & 21 & 0 \\
\hline 23 & 1 & 69 & -68 \\
\hline 24 & 20 & 1 & 19 \\
\hline 25 & 9 & 5 & 4 \\
\hline 26 & 13 & 1 & 12 \\
\hline 27 & 13 & 0 & 13 \\
\hline 28 & 34 & 0 & 34 \\
\hline 29 & 64 & 1 & 63 \\
\hline 30 & 18 & 2 & 16 \\
\hline 31 & 21 & 2 & 19 \\
\hline 32 & 2 & 1 & 1 \\
\hline 33 & 25 & 2 & 23 \\
\hline 34 & 49 & 2 & 47 \\
\hline 35 & 13 & 1 & 12 \\
\hline 36 & 31 & 1 & 30 \\
\hline 37 & 17 & 1 & 16 \\
\hline
\end{tabular}




\begin{tabular}{|c|c|c|c|}
\hline 38 & 8 & 1 & 7 \\
\hline 39 & 11 & 2 & 9 \\
\hline 40 & 14 & 0 & 14 \\
\hline 41 & 14 & 2 & 12 \\
\hline 42 & 40 & 1 & 39 \\
\hline 43 & 7 & 4 & 3 \\
\hline 44 & 17 & 4 & 13 \\
\hline 45 & 8 & 1 & 7 \\
\hline 46 & 13 & 3 & 10 \\
\hline 47 & 16 & 1 & 15 \\
\hline 48 & 18 & 1 & 17 \\
\hline 49 & 8 & 2 & 6 \\
\hline 50 & 6 & 2 & 4 \\
\hline 51 & 3 & 1 & 2 \\
\hline 52 & 23 & 1 & 22 \\
\hline 53 & 14 & 17 & -3 \\
\hline 54 & 6 & 8 & -2 \\
\hline 55 & 42 & 8 & 34 \\
\hline 56 & \begin{tabular}{|l|}
25 \\
\end{tabular} & 7 & 18 \\
\hline 57 & \begin{tabular}{|l|}
8 \\
\end{tabular} & 7 & 1 \\
\hline 58 & 6 & 8 & -2 \\
\hline 59 & \begin{tabular}{|l|}
16 \\
\end{tabular} & 7 & 9 \\
\hline 60 & \begin{tabular}{|l|}
46 \\
\end{tabular} & 4 & 42 \\
\hline 61 & 12 & 14 & -2 \\
\hline 62 & \begin{tabular}{|l|}
49 \\
\end{tabular} & 21 & 28 \\
\hline 63 & 15 & 1 & 14 \\
\hline 64 & \begin{tabular}{|l|}
7 \\
\end{tabular} & 1 & 6 \\
\hline 65 & 6 & 1 & 5 \\
\hline 66 & \begin{tabular}{|l|}
13 \\
\end{tabular} & 1 & 12 \\
\hline 67 & \begin{tabular}{|l|}
23 \\
\end{tabular} & 1 & 22 \\
\hline 68 & 12 & 1 & 11 \\
\hline 69 & 103 & 13 & 90 \\
\hline 70 & 6 & 1 & 5 \\
\hline 71 & \begin{tabular}{|l|}
1 \\
\end{tabular} & 1 & 0 \\
\hline 72 & 38 & 0 & 38 \\
\hline 73 & \begin{tabular}{|l|}
56 \\
\end{tabular} & 0 & 56 \\
\hline 74 & \begin{tabular}{|l|}
26 \\
\end{tabular} & 4 & 22 \\
\hline 75 & \begin{tabular}{|l|}
26 \\
\end{tabular} & 1 & 25 \\
\hline 76 & 1 & 1 & 0 \\
\hline 77 & 26 & 2 & 24 \\
\hline 78 & \begin{tabular}{|l|}
7 \\
\end{tabular} & 2 & 5 \\
\hline 79 & \begin{tabular}{|l|}
13 \\
\end{tabular} & 0 & 13 \\
\hline 80 & \begin{tabular}{|l|}
21 \\
\end{tabular} & 1 & 20 \\
\hline 81 & 1 & 1 & 0 \\
\hline 82 & \begin{tabular}{|l|}
17 \\
\end{tabular} & 9 & 8 \\
\hline 83 & \begin{tabular}{|l|}
7 \\
\end{tabular} & 2 & 5 \\
\hline 84 & 11 & 2 & 9 \\
\hline 85 & 9 & 0 & 9 \\
\hline 86 & 2 & 1 & 1 \\
\hline 87 & \begin{tabular}{|l|}
33 \\
\end{tabular} & 1 & 32 \\
\hline 88 & 2 & 1 & 1 \\
\hline 89 & 9 & 1 & 8 \\
\hline 90 & 113 & 1 & 112 \\
\hline 91 & 15 & 1 & 14 \\
\hline 92 & 5 & 0 & 5 \\
\hline 93 & 23 & 2 & 21 \\
\hline 94 & 8 & 2 & 6 \\
\hline 95 & 54 & 2 & 52 \\
\hline 96 & 87 & 2 & 85 \\
\hline 97 & 18 & 0 & 18 \\
\hline 98 & 74 & 0 & 74 \\
\hline 99 & 33 & 11 & 22 \\
\hline 100 & 2 & 6 & -4 \\
\hline 101 & 1 & 1 & 0 \\
\hline 102 & 6 & 10 & -4 \\
\hline 103 & 3 & 14 & -11 \\
\hline 104 & 6 & 0 & 6 \\
\hline Average length & 21 & 5 & 16 \\
\hline
\end{tabular}

As shown in table 1, among the recorded 104 turns of T-S interactions, only 9 times, the student speaks more than the teacher. The average length of teacher talk is 21 words while the average length of student talk is 5 words. This suggests 
that teacher talk still a way outweighs student talk in this class despite the teacher's effort to elicit more student talk. Although most teacher talks are longer than student talks, students do show some consciousness to respond in sentences rather than individual words, even though they make grammatical mistakes. This manifests that students do accept the teacher's suggestion of conducting this reading lesson in a communicative way, they are making efforts to speak more.

TABLE 2.

TURNS WHERE ST OUTWEIGHS TT

\begin{tabular}{|c|c|c|}
\hline T-S Interaction Turn No. & Teacher Talk & Student Talk \\
\hline 8 & Yes, it's unusual. Why it's unusual? & $\begin{array}{l}\text { The narrator says, when the telephone rings, he } \\
\text { doesn't answer it. So, I don't understand. }\end{array}$ \\
\hline 10 & $\begin{array}{l}\text { Uh uh. You think it's narrative, instead } \\
\text { of argument. }\end{array}$ & $\begin{array}{l}\text { I think, maybe just one person in, in this article, only } \\
\text { the author in the text. Just one character. It's just the } \\
\text { narrator. }\end{array}$ \\
\hline 13 & $\begin{array}{l}\text { Yah, Why it's argument? What's the } \\
\text { difference between narrative and } \\
\text { argument? }\end{array}$ & $\begin{array}{l}\text {...narrative I think, it's usually the author speaks one } \\
\text { things but the argument but the argument always say } \\
\text { something about the questions and express the } \\
\text { author's ideas of..... }\end{array}$ \\
\hline 23 & OK... & $\begin{array}{l}\text { And just like, he mentioned having supper or talking } \\
\text { with somebody when the telephone rang. And he was } \\
\text { unwillingly and reluctant to answer it. This is one } \\
\text { event in the article, And he also, also give some } \\
\text { examples like, through the telephone, he'll know the } \\
\text { elope of....a friend, or his friend, maybe have a bad } \\
\text { accident at once. And he also, also gave some } \\
\text { examples who need the telephone. }\end{array}$ \\
\hline 53 & $\begin{array}{l}\text { Yes, line } 31 . \text { What does this word } \\
\text { mean? Can someone read out the } \\
\text { sentences? }\end{array}$ & $\begin{array}{l}\text { It serves you right if you find it impossible to escape } \\
\text { from some idle or inquisitive chatterbox. }\end{array}$ \\
\hline 58 & I bent on, is that right? & I am bent on becoming a good teacher. \\
\hline 61 & $\begin{array}{l}\text { Yes, what does this word mean, can } \\
\text { you speak that again? elope }\end{array}$ & $\begin{array}{l}\text { "elope" means to run away secretly with a., with a } \\
\text { lover and get married. }\end{array}$ \\
\hline 101 & Ok. & $\begin{array}{l}\text { But I think the mobile phone... Keep touch with our } \\
\text { friends... }\end{array}$ \\
\hline 102 & Yes, what else? & $\begin{array}{l}\text { When we meet some difficulties, we also can use } \\
\text { mobile phone call our friends. }\end{array}$ \\
\hline
\end{tabular}

Looking into the 9 T-S interactions in table 2 in which student talks are longer than teacher talks, I found in these interactions, teacher talks are teacher-initiated "Why" questions, for instance: turn 8 and turn 13; or the teacher intends to elicit student's further explanation by simply repeating the student's previous answer such as in turn 10 or by asking a what question such as "what else?" in turn 10 and "What does this word mean?" in turn 53 and 61; or an encouraging "ok..."such as in turn 23. These suggest that why and what questions and encouraging tone can elicit more student talk.

\section{B. Teacher-student Interaction Pattern}

The transcribed recording showed that the teacher-student interaction patter follows IRF pattern recognized by many scholars. Here are a few examples of the IRF pattern that appear in the transcript:

(1)

T: Yes. So, what does inquisitive mean?

S:A person who is curious about other people.

T: right. A person who is curious about other people.yeah. So, inquisitive means "curious", right? And usually it denotes unduly curious. And next line, line 32, we have the phrase bent on. bent on. What does the phrase mean? Bent on doing something.

(2)

T: Can somebody make a sentence using "bent on"?

S1: I bent on becoming a good teacher.

T: I bent on, is that right?

S2: I am bent on becoming a good teacher.

T: So, after bent on, you use v-ing form. Can you make a sentence again using "bent on"?

As shown in the above examples, teacher-student interactions usually start with a teacher-initiated question. Students are always in the position to answer the questions, followed by the teacher's feedback to the student's answers. In many cases, another teacher-initiated question will follow the feedback as in example 2.

\section{Characteristics of Teacher Talk in This Recording}

\section{Teacher-initiated question types}

Teacher-initiated questions accounted for a large proportion in the teacher-student interaction. Meng \& Wang identified some reasons why questions are so commonly used in teaching. "Questions stimulate and maintain students' 
interest and encourage student participation in a lesson. They encourage a teacher to think and focus on the content of the lesson, enable the teacher to clarify what a student has said, to elicit particular structures or vocabulary items and to check students' understanding." (Meng \& Wang 2011:101)

In my transcribed recording, the most frequently asked question is "what does... mean?". The question appeared 18 times. I asked the questions to check the students' understanding of the word meaning in the text and to elicit an answer from the student. I also used alternative questions a lot. For example:

(1). Right, is he giving the reasons of his own or is he giving the reasons of some other people why they don't answer the telephone?

(2). Can a pest only be a person or can it be something?

(3).Can somebody breathe or cannot breathe?

(4). Cautious or uncautious?

(5).So, here, is "obstinacy" a noun or is it an adjective?

(6).Is it a noun or an adjective?

(7).How about willfulness? Is it a noun or an adjective?

(8).Beautiful is a one word or two-word adjective?

Alternative questions are closed questions with predictable answers. Closed questions usually elicit short responses. Why do I use alternative questions so often? The purpose is to provide hints and direct the students' way of thinking and elicit some kind of student talk. Especially when I posed a what question or why question and got no response from the students, I used alternative question to elicit an answer.

\section{Repetition}

Another striking characteristic of the teacher talk is that I repeated a lot. I repeated nearly every question at least twice, and I often repeated the last phrase of the previous sentence. I also repeated the students' answers. For example:

T: If you don't have any questions. Let me ask you some questions. I'm going to ask you to explain some words in your own words. Ok. Some vocabulary in your own words. Let's see, "pose" and "pest". You can see the two words in Paragraph 2, right? Paragraph 2, line 4. "I pretend to be wise or pose as unusual." What does "pose” mean?

S: Pretend.

T: Yes, pretend, good! And pest. Can you find this word in the article? In paragraph 2, which line?

S: Line 7.

T: Line 7, right. Ok. "I think it's a pest and time waste." What does pest mean? How do you understand "pest"?

$S$ : Annoying thing.

T: What thing?

$S$; Annoying be...

T: Annoying thing. Ok. Uh. Can a pest only be a person or can it be something? It can either be something or it can

S: a person.

T: A person.....

I repeated to make sure that the students can understand me better. In the meantime, repeating what was said by the student can give myself some time to think about what to say next. Repetition of the meaning of a new word gave the student one more chance to learn the word and memorize it.

\section{Idiosyncratic language}

The third conspicuous feature of my teacher talk is that I said the following words many times: "Yes, OK. Right. Good." These repeated words serve different purposes. They were used to draw students' attention. For example: "Ok, Good morning." They were used to encourage or to praise the student for giving the right answer. For example:

(1). S: prefix.

T: Right! Prefix. And what does this prefix mean?

(2). S: ness.

T: Yeah, from "ness".

Or, they were used to introduce a new topic or new activity. For example:

T: Ok. Good. Yeah. Now, let's have group discussions.

\section{Conscious self-correction}

The fourth characteristic of my teacher talk is that I consciously corrected my own mistakes in my teacher talks. For example:

(1). That's on line, in line 8, can someone think of a synonym for irritating?

(2).That's on line, in line 31 .

(3). That's on line, in line 33.

(4). That's on line, in line 45.

(5).Any more sentences, questions?

(6).Can all you find, can all of you find this word in the text book? Bed-ridden?

(7).What kind of adjective do you call this one, this word?

(8).If a place is very background, backward, we can call the place a poverty-stricken area. 
(9).From, in terms of word formation...

While transcribing the recording, I asked myself why I corrected my own mistakes when realizing them, instead of ignoring them to avoid the risk of letting the students know that the teacher did not speak perfect English. My answer was this: I wanted to show the students that honesty was very important in learning. As a teacher of English, I acquired English in China. It is true that I am always an English language learner myself. It's quite possible that I still make mistakes even though I am a more advanced learner. As a teacher, I realized that the language I used in class often served as the model for the students, so I tried my best to speak grammatically correct language in class. In the meantime, my attitude towards learning and my own way of learning English and can influence my students as well. It's my responsibility to let the students know that making mistakes and learning from one's own mistakes is part of language learning. Self-correction is a way to show that you are able to recognize and solve your own problem. It's a technique to facilitate language learning.

\section{Vocalized pauses}

Vocalized pauses appear sometimes in the recording. The causes for these vocalized pauses can be grouped into the following categories: elicitation of answers from students; an indication of topic/activity transfer; a preliminary to an attempt to rephrase what I've just said.

\section{My feedback to the students' inappropriate answers}

Instead of telling them directly the answer was incorrect, I asked the other students whether the answer given by a student was right, trying to get other students to come up with a correct answer. I also asked the student to explain his/her answer so that the others knew why he or she was right or wrong. For example:

(1).

T: Can somebody make a sentence using "bent on"?

S1: I bent on becoming a good teacher.

T: I bent on, is that right?

S2: I am bent on becoming a good teacher.

(2).

T: Can someone give an answer to question No. 2? Do we have any volunteer? ....Cheng Li

S: I think maybe the first one, narrative. er.

T: Uh huh. You think it's narrative, instead of argument.

S: I think, maybe just one person in, in this article, only the author in the text. Just one character. It's just the narrator.

T: So, there is only one narrator in the whole article. Do you agree?(to the whole class) Do you think this text is a narrative?

S1: Yes.

S2; It's argument.

T: Yes, you think it's argument. Right?

S; Yes.

T: Yah, Why it's argument? What's the difference between narrative and argument?

I didn't mind their broken sentences. I believed that the most important thing was to let them feel free to speak out whatever was on their mind to demonstrate that they had read the text and had formed their own opinion on the topic. I always said to my students, "you have to show me your understanding of the text by speaking out." I encouraged any kind of response and praised highly the correct responses.

\section{CONCLUSION AND Discussion}

The transcription of the class recording shows that teacher talk in this reading class follows the IRF or IRE pattern recognized by many other researchers. Although guided by the communicative teaching approach, teacher talk still far outweighed in this lesson. In accordance with the teaching objectives of the class and teaching tasks, teacher initiated questions were mostly about the meaning of words in context and formation of compound words. I repeated a lot to draw students' attention and enhance their understanding. I allowed some vocalized pauses to give the students time to think and organize their speech. I tried to elicit students talk and directed their way of thinking by using alternative questions or tag questions when the students were relatively quiet and not competent enough to express themselves. After each explanation, I asked questions to check their comprehension. For example, after the explanation of some phrase, I asked the students to use the phrases to make sentences. And after I explained the concept of compound adjective, I checked their comprehension by asking them to explain the concept again and provide examples. At this stage, I only corrected the mistakes such as the wrong use of adjectives and stress problems in pronunciation. By doing this, I wanted to show the students that we "have a focus in different unit at different stage." I consciously did self-correction when realizing mistakes in my own speech. In so doing, I tried to tell the students that making mistakes and correcting one's own mistakes were part of learning language.

The findings of this research agree with some studies that have reported the dominance of teacher talk, the persistence of initiation-response-feedback as the principal form of discourse, the brevity of student responses and the lack of sustained interaction with individuals (see, e.g., Smith et al., 2006). 
One of the multiple roles a teacher plays in communicative activities is that the teacher acts the resource (Sinclair \& Coulthard, 1975), which means that teacher talk in the language classroom can be regarded as the language input. Therefore, it is of paramount importance for EFL teachers to be aware of the characteristics of their discourse, for it is one of the most beneficial tools which is at the hand of teachers and has a great effect on reducing learners' affective filter. Teachers should be able to have an initial view of how to establish rapport with learners, though learning how to relate to learners takes time and requires good knowledge (Zargham Ghabanchi \& Shirin Malekzadeh, 2011). Concluding from the aforementioned information, for every responsible teacher who is keen to improve the quality of his/her teaching, improving the quality of teacher discourse should be one of the priorities.

\section{Limitations of the PRESENT Study AND SUGgestions FOR Future RESEARCH}

Although the findings of the present research may shed some light on the general pattern and characteristics of teacher talk in one language classroom in Chinese universities, because of the size of the class and length of the recording, the results of the research cannot be generalized to more language classrooms. In addition, I myself made the recording and did the transcription, analyzed and reflected on everything on my own, and I may have ignored some important features of teacher talk. Therefore, in the future, if another teacher observes or listens to the recording and analyzes the data, something new and more interesting may be explored.

\section{REFERENCES}

[1] Allwright, R. L. (1984). The importance of interaction in classroom language learning. Applied Linguistics, 5, 156-171.

[2] Casa, T. M., \& DeFranco, T. C. (2002). Examining the nature and role of discourse in the teaching of mathematics: A case study of two preservice teachers. Retrieved January 14, 2011, from http://www.education.duq.edu/institutes/ PDF/papers2002/Casa_DeFranco.pdf

[3] Cazden, C. B. (1986). Classroom discourse. In M. C. Wittrock (Ed.), Handbook of research on teaching (3rd ed., pp. 432-464). New York: Macmillan

[4] Cazden, C. B. \& Beck, S. W. (2003). Classroom discourse. In A. C. Graesser, M. A. Gernsbacher \& S. R. Goldman (Eds.), Handbook of discourse processes (pp.165-197). Mahwah, NJ: Erlbaum.

[5] Chaudron, C. (1982). Vocabulary elaboration in teachers' speech to L2 learners. Studies in Second Language Acquisition, No.4, $170-180$.

[6] Chaudron, C. (1988). Second Language Classrooms: Research on Teaching and Learning. Cambridge: Cambridge University Press.

[7] Ellis, Rod \& Barkhuizen, Gary. (2005). Analyzing Learner Language. Oxford: Oxford University Press.

[8] Gaies, S. J. (1977). The nature of linguistic input in formal second language learning: Linguistic and communicative strategies in ESL teachers' classroom language. In H. D. Brown, C. A. Yorio, \& R. H. Crymes (Eds.), On TESOL '77: Teaching and learning English as a second language: Trends in research and practice (pp. 204-212). Washington, DC: TESOL.

[9] Gaies, S. J. (1979). Linguistic input in first and second language learning. In F. Eckman \& A. Hastings (eds.), Studies in First and Second Language Acquisition. Rowley. Mass: Newbur House.

[10] Ghabanchi, Zargham \& Malekzadeh, Shirin. (2011) The Study of EFL Teacher Discourse in Reading Skill--Using Bloom's Cognitive Taxonomy. International Journal of Linguistics Vol. 3, No. 1, E18 doi:10.5296/ijl.v3i1.812

[11] Harmer, J. (2005). The Practice of English language Teaching ( $3^{\text {rd }}$ edition). Harlow: Longman.

[12] Hedge, T. (2002). Teaching and Learning in the Language Classroom. Shanghai: Shanghai Foreign Language Education Press.

[13] Hellermann, J. (2003). The interactive work of prosody in the IRF exchange: Teacher repetition in feedback moves. Language in Society, Vol.32: 79-104. Retrieved December 19, 2011, from http://journals.cambridge.org/action/displayAbstract?fromPage=online\&aid=136817

[14] Howard, Amanda. (2010). Is there such a thing as a typical language lesson? Classroom Discourse, Vol. 1, Issue 1, 82-100

[15] Liu, Yanfen \& Zhao Yuqin. (2010). A Study of Teacher Talk in Interactions in English Classes. Chinese Journal of Applied Linguistics. Vol. 33, No. 2, 76-86

[16] Long, M.H. (1981). Input, Interaction and Second Language Acquisition. In Winnitz (ed.): Native Language and Foreign Acquisition. Annals of the New York Academy of Sciences 379, 259-78.

[17] Long, M.H. (1983). Native Speaker / Non-native Speaker Conversation and the negotiation of Comprehensible Input. Applied Linguistics Vol. 4, No.2, 126-41.

[18] McCarthy, M. (2002). Discourse Analysis for Language Teachers. Shanghai: Shanghai Foreign Language Education Press.

[19] Meng, Xuemei \& Wang, Xuesong. (2011). Action Study of Teacher's Language on EFL Classroom Interaction. Theory and Practice in Language Studies. Vol. 1, No. 1, pp. 98-104 doi:10.4304/tpls.1.1.98-104

[20] Mercer, N. (1995). The Guided Construction of Knowledge. Clevedon: Multilingual Matters.

[21] Mortimer, E. F., Machado, A. H. (2000). Anomalies and Conflicts in Classroom Discourse. Science Education, Vol. 84, 429 444.

[22] Sinclair, J. M., \& Coulthard, R. M. (1975). Towards an analysis of discourse: The English used by teachers and pupils. London: Oxford University Press.

[23] Sinclair, J.M \& D. Brazil. (1982). Teacher Talk. London: Oxford University Press.

[24] Smith, F. et al. (2006). The impact of interactive whiteboards on teacher-pupil interaction in the National Literacy and Numeracy Strategies, British Educational Research Journal. Vol. 32, No.3, 443-457

[25] Viiri, J \& Saari, H. (2006). Teacher Talk Patterns in Science Lessons: Use in Teacher Education. Journal of Science Teacher Education. Retrieved December 20, 2011, from http://www.springerlink.com/index/Q838705076411617.pdf 
[26] William Littlewood and Baohua Yu. (2011). First language and target language in the foreign language classroom. Language Teaching, 44, pp 64-77 doi:10.1017/S0261444809990310

[27] Willis, J \& Willis, D(Eds.) (2002). Challenge and Change in Language Teaching. Shanghai: Shanghai Foreign Language Education Press.

[28] XU, Xiao-hui. (2010). Analysis of Teacher Talk on the Basis of Relevance Theory. Canadian Social Science Vol. 6, No. 3, pp. 45-50. Retrieved December 20, 2011 from http://www.cscanada.net/index.php/css/article/view/1072/1091

[29] Zargham Ghabanchi \& Shirin Malekzadeh. (2011). The Study of EFL Teacher Discourse in Reading Skill--Using Bloom's Cognitive Taxonomy. International Journal of Linguistics. Vol. 3, No. 1.E18.

Ping Zhang got her MA Degree in Linguistics from Nanjing University in 2000. She is now associate professor in English Department, School of Foreign Language Studies, Nanjing University of Aeronautics and Astronautics. 